\title{
SPREMINJANJE TEMPERATUR NA GORENJSKEM V OBDOBJU I96I-2010
}

\author{
Miha Klemenčič*, Neža Marolt*, dr. Matej Ogrin**, Estera Popovič* \\ *Študent/ka geografije na Oddelku za geografijo Filozofske fakultete Univerze v Ljubljani \\ **Oddelek za geografijo, Filozofska fakulteta Univerze v Ljubljani, \\ Aškerčeva 2, SI-I000 Ljubljana \\ e-mail: miha.klemencic2@gmail.com, nezi.marolt@gmail.com, matej.ogrin@ff.uni-lj.si, \\ estera.popovic@gmail.com
}

Izvirni znanstveni članek

COBISS 1.01

DOI: $10.4312 /$ dela.40.5.73-89

\section{Izvleček}

Podnebne spremembe zaradi globalnega ogrevanja ozračja so realnost in obstajajo precej jasni podatki o spremembah globalne temperature planeta ali njegovih delov, kot so kontinenti, oceani in gorske verige. Nekoliko manj je študij za manjše regije ali pokrajine. Prispevek govori o temperaturnih spremembah na Gorenjskem od leta 1961 do $2010 \mathrm{v}$ obliki primerjave dveh 30-letnih obdobij (1961-1990 in 1981-2010) in tudi prikaza linearnih trendov zadnjega 30-letnega obdobja. Upoštevali smo podatke o temperaturah na petih meteoroloških postajah, dveh nižinskih, eni dolinski, eni sredogorski in eni visokogorski.

Ključne besede: Slovenija, Gorenjska, podnebne spremembe, ogrevanje ozračja, klimatogeografija

\section{TEMPERATURE CHANGES OF GORENJSKA REGION IN THE PERIOD I96I-20IO}

\begin{abstract}
Climate changes and global warming are a reality. Many data of global temperature increase are available in large spatial scales, such as continents, mountain chains or whole Earth. However, we are still missing such studies from regions on smaller spatial scale. The article is focused on temperature changes in Gorenjska region in the period 1961-2010. We compared two 30-years periods (1961-1990 and 1981-2010) and calculated some linear temperature trends of last period (1981-2010) from five meteorological stations: two from lowland, one from Alpine valley, one from hilly terrain and one from high mountains.
\end{abstract}

Key words: Slovenia, Gorenjska region, climate changes, global warming, climatogeography 


\section{UVOD}

20. stoletje in še posebej njegovo drugo polovico je zaznamoval globalen dvig temperature, ki ga povezujemo s človekovim vplivom na Zemljin podnebni sistem in mu pravimo tudi povečan učinek tople grede. Slovenija s svojo lego v zmernih geografskih širinah na robnem območju Alp in Sredozemlja doživlja podobne trende (Ogrin, 2003; Dolinar, Vertačnik, 2010). To se kaže tudi v letnih časih, saj zime postajajo vse manj snežene, poletja pa vse bolj vroča.

V strokovni literaturi je bilo podnebju Gorenjske namenjenih kar nekaj del. Najnovejši je prispevek o splošnih podnebnih razmerah Gorenjske (Ogrin, D., Vysoudil, Ogrin, M., 2013). V njem je poleg podnebnih razmer podan tudi obširnejši pregled literature na to temo, ki smo ga na tem mestu izpustili.

$\mathrm{V}$ tem prispevku se posvečamo predvsem spreminjanju temperaturnih razmer na Gorenjskem. Naraščanje povprečnih temperatur zraka v hladni polovici leta in povečanje števila t. i. zelenih zim bo pomembno vplivalo na dejavnosti v tem delu Slovenije, predvsem na zimskošportni turizem, saj je na Gorenjskem kar nekaj smučarskih centrov in manjših, nižje ležečih smučišč. Tej tematiki se je posvetila Vrtačnik Garbas v svoji disertaciji (2008) in nakazala precejšnjo ranljivost slovenskih zimskošportnih središč za podnebne razmere. Raziskava, ki je bila posebej opravljena za preučitev snežnih razmer na smučišču Španov vrh, je nakazala velik upad števila dni s snežno odejo nad $50 \mathrm{~cm}$ in tudi števila dni s snežno odejo nad $30 \mathrm{~cm}$ (Ogrin M. in sod., 2009; Ogrin M. in sod., 2011), širša raziskava pa tem rezultatom pritrjuje in podaja podobne ugotovitve tudi za druge alpske pokrajine v Sloveniji (Ogrin M. in sod., 2011).

Gledano v širšem merilu, izkazuje Evropa od leta 1979 višji porast temperature kot je globalno povprečje (Böhm in sod.,2001; cv: Neu, 2009, str. 9), gorska območja pa kažejo še večjo intenzivnost ogrevanja, na regionalni ravni kar 1,5-krat hitrejšo kot je globalno povprečje, pri čemer se poletja segrevajo hitreje (Neu, 2009, str. 9.) Prispevek se osredotoča na temperaturne trende 30-letnega obdobja na Gorenjskem, pod drobnogled pa vzame tudi t. i. karakteristične dneve, ki nam izkazujejo temperaturne lastnosti nekega podnebja.

\section{METODE DELA}

Za analize temperaturnih sprememb smo izbrali podatke iz spletnega arhiva Agencije Republike Slovenije za okolje (ARSO). Izbrali smo tridesetletni niz podatkov za obdobje 1981-2010, podatke pa smo v nekaterih primerih primerjali tudi s 30-letnim obdobjem 1961-1990. Iz njih smo izračunali linearne trende, ki kažejo spremenljivost temperaturnih razmer v referenčnem obdobju. Obravnavali smo povprečne dnevne, povprečne najnižje dnevne in povprečne najvišje dnevne temperature. Povprečna dnevna temperatura je ena četrtina vsote temperatur ob 7. uri, ob 14. uri in dvakrat ob 21. uri po Sončevem času. Je osnovni podatek za računanje povprečne mesečne in povprečne letne temperature. Povprečna najvišja dnevna temperatura je povprečje najvišjih dnevnih temperatur, torej je aritmetična sredina najvišjih temperatur. 
Povprečna najnižja temperatura je povprečje najnižjih dnevnih temperatur, oziroma aritmetična sredina najnižjih dnevnih temperatur. Oba parametra nekako nakažeta povprečne intervale dnevnih temperatur med letom in sta kot taka primerna kazalca temperaturnih razmer.

Obravnavali smo tudi t. i. karakteristične dneve, to so mrzli dnevi, ledeni dnevi, hladni dnevi, topli dnevi in vroči dnevi. Uporaba karakterističnih dni je zelo primeren način predstavitve temperaturnih razmer, saj si ljudje brez večjih težav predstavljamo, kaj pomeni npr. dnevna temperatura nad $25^{\circ} \mathrm{C}$ ali nad $30{ }^{\circ} \mathrm{C}$, najnižja dnevna pod $0{ }^{\circ} \mathrm{C}$ ali pod $-10{ }^{\circ} \mathrm{C}$.

Mrzel dan je dan, ko temperatura pade pod $-10{ }^{\circ} \mathrm{C}$. V zmerno toplem podnebju so mrzli dnevi pokazatelj mrzle, lahko tudi ostre zime. Leden dan je, kadar najvišja dnevna temperatura ne doseže $0{ }^{\circ} \mathrm{C}$ oziroma je ves dan pod lediščem. Podobno kot pri mrzlih dneh tudi za ledene dni velja, da so za naše razmere pokazatelj hude zime. Po nižinah Slovenije se večinoma pojavljajo od decembra do konca februarja, izjemoma tudi v že v novembru ali še v marcu. Hladen dan je, kadar najnižja dnevna temperatura pade pod $0{ }^{\circ} \mathrm{C}$. Gre za precej pogost pojav v slovenskih pokrajinah, ki se po nižinah lahko pojavlja od oktobra (zelo redko tudi že v septembru) do aprila, izjemoma še v maju. Zlasti od novembra do marca so takšni dnevi zelo pogosti.

Topel dan je, kadar najvišja dnevna temperatura preseže $25^{\circ} \mathrm{C}$. Taki dnevi se pojavljajo predvsem od konca aprila do konca septembra ali začetka oktobra. Poleti so taki dnevi nekaj običajnega. Vroč dan je, kadar najvišja dnevna temperatura preseže $30{ }^{\circ} \mathrm{C}$. Ti dnevi so zelo dober pokazatelj poletnih razmer, saj temperature nad $30{ }^{\circ} \mathrm{C}$ smatramo za vroče vreme in so indikator 'pravega' poletja. Dan s toplo nočjo je, kadar najnižja dnevna temperatura ne pade pod $20^{\circ} \mathrm{C}$. Taki dnevi oziroma take noči se pojavljajo redko, v zadnjih letih pa se njihova pogostnost zvišuje. Njihov porast beležimo zlasti v mestnih območjih, kjer se ob vročinskih valovih zrak ponoči zaradi pregretosti mestnih površin ne shladi dovolj. Sicer so v Sloveniji precej bolj pogosti v morskih krajih, njihova prisotnost pa se kaže kot dejavnik povečane toplotne obremenitve.

Težave pri delu so bile predvsem v manjkajočih podatkih, nepopolnih časovnih nizih, spremembah lokacije merilnih mest in ukinitvah meritev na določenih meteoroloških postajah. Na podlagi tega smo izločili postaje, ki bi sicer bile na območju Gorenjske in bi nam zelo koristile, vendar so bili nizi podatkov preveč okrnjeni oziroma nesklenjeni, da bi bilo njihovo vrednotenje na podlagi linearnega trenda smiselno.

Po pregledu delujočih meteoroloških postaj smo izbrali naslednje:

- Ljubljana-Bežigrad (nadmorska višina 299 m): glavna meteorološka postaja, leži v Ljubljanski kotlini v središču Ljubljane. Zaradi učinka mestnega toplotnega otoka (Jernej, 2000) predstavlja temperaturne razmere le na območju mesta.

- Lesce $(515 \mathrm{~m})$ : klimatološka postaja na severozahodnem robu Ljubljanske kotline in predstavlja ravninski del osrednje Gorenjske in njegove podnebne značilnosti.

- Rateče (864 m): glavna klimatološka postaja, referenčna zaradi stalne lokacije in nespremenjene okolice. Leži v Dolini, ki je tipična alpska dolina in predstavlja podnebne značilnosti tega pokrajinskega tipa. 
- Planina pod Golico (970 m): lega nad dnom Doline oziroma nad jezerom hladnega zraka; lahko bi jo uvrstili kar v 'alpski termalni pas', za katerega so značilne nekoliko višje minimalne temperature in večja osončenost kot na dnu doline.

- Kredarica $(2514 \mathrm{~m})$ : najvišje ležeča glavna meteorološka postaja, zastopa podnebne značilnosti visokogorja.

Slika 1: Meteorološka postaja Rateče je tipična za alpske doline, hkrati se njena okolica ni bistveno spreminjala, kar zelo vpliva na kakovost podatkov (foto: M. Ogrin)

Figure 1: Meteorological station Rateče is typical station for Alpine valleys. The surrounding of the station hasn't changed since measurements started what is good for quality of the data (photo: M. Ogrin)

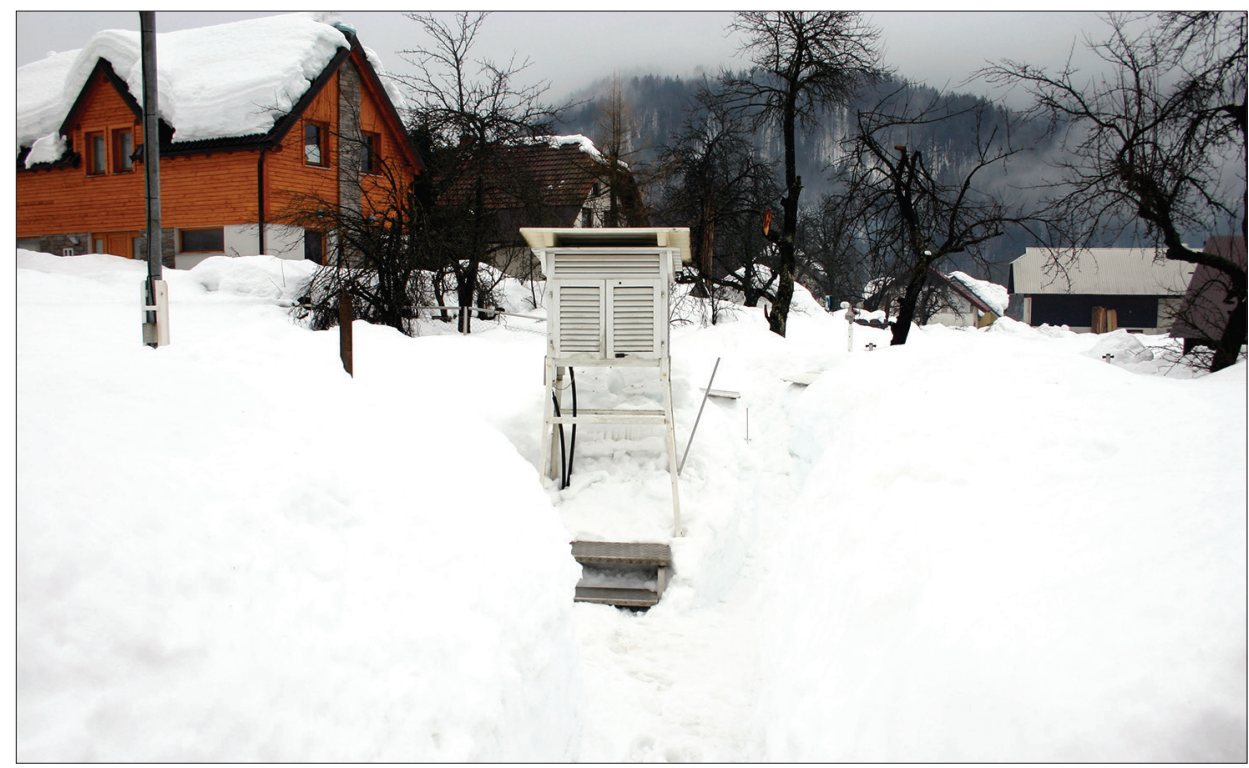

\section{REZULTATI}

V analizo temperaturnih izračunov smo vključili meteorološke postaje s 30-letnim nizom podatkov in kjer ni prišlo do spremembe lege postaje. Tako smo analizirali pet postaj, in sicer tri glavne meteorološke postaje - Kredarica (2514 m), Ljubljana-Bežigrad $(299 \mathrm{~m})$ in Rateče $(864 \mathrm{~m})$ ter dve klimatološki postaji - Lesce $(515 \mathrm{~m})$ in Planina pod Golico (970 m).

Povprečna dnevna temperatura kaže trend zviševanja na vseh meteoroloških postajah (slika 2). Najhitreje se je zviševala na postajah Ljubljana-Bežigrad in Lesce, najpočasneje na Kredarici. V obravnavanem obdobju to pomeni za Ljubljano dvig temperature za $2,0{ }^{\circ} \mathrm{C}$, za Lesce in Rateče $1,5^{\circ} \mathrm{C}$, za Planino pod Golico $1,2{ }^{\circ} \mathrm{C}$ ter le za $0,7{ }^{\circ} \mathrm{C}$ na Kredarici (preglednica 1). 
Slika 2: Spreminjanje povprečne dnevne temperature z linearnimi trendi na izbranih meteoroloških postajah v obdobju 1981-2010

Figure 2: Changing of mean daily temperatures with linear trends on chosen meteorological stations in the period 1981-2010

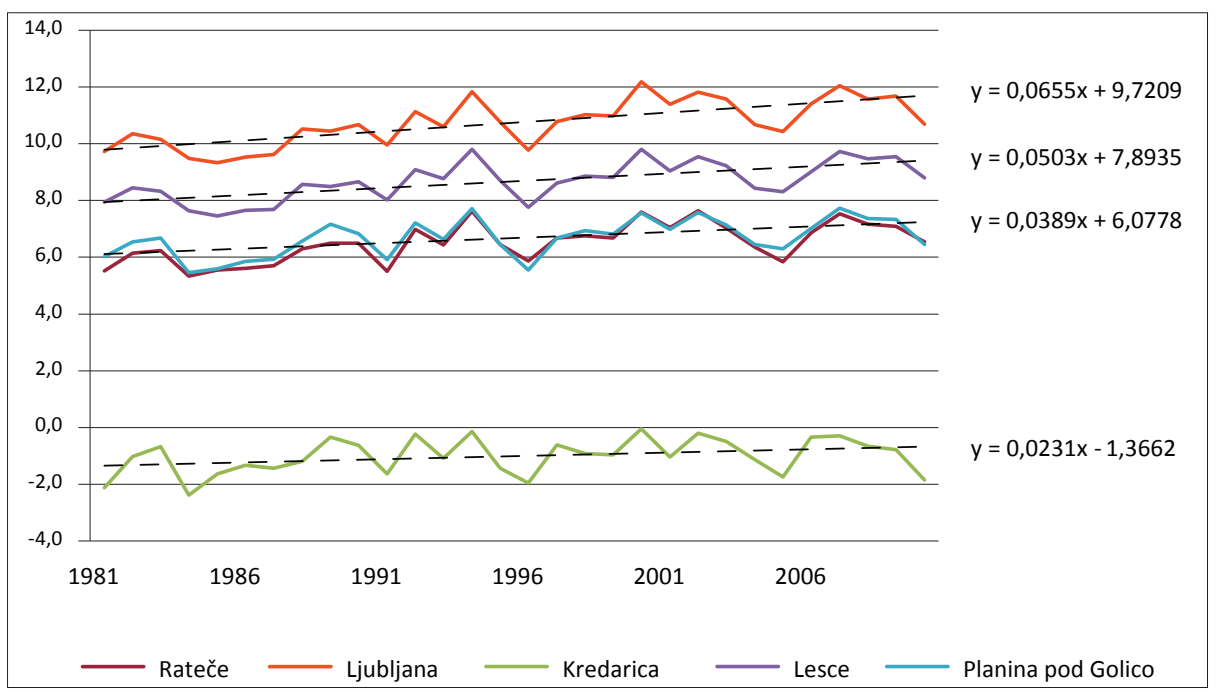

Vir/Source: Arhiv ARSO, 2012

Slika 3: Spreminjanje povprečne najvišje dnevne temperature z linearnimi trendi na izbranih meteoroloških postajah v obdobju 1981-2010

Figure 3: Changing of mean maximum daily temperatures with linear trends on chosen meteorological stations in the period 1981-2010

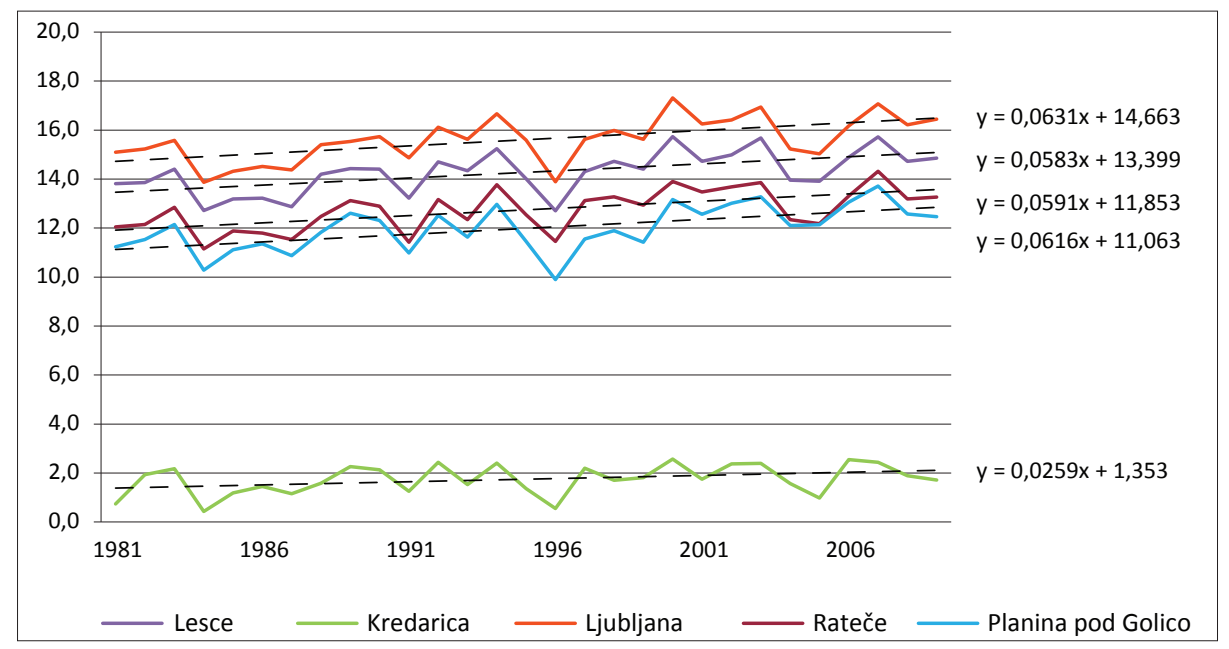

Vir/Source: Arhiv ARSO, 2012 
Slika 4: Spreminjanje povprečne najnižje dnevne temperature z linearnimi trendi na izbranih meteoroloških postajah v obdobju 1981-2010

Figure 4: Changing of mean minimum daily temperature with linear trends on chosen meteorological stations in the period 1981-2010

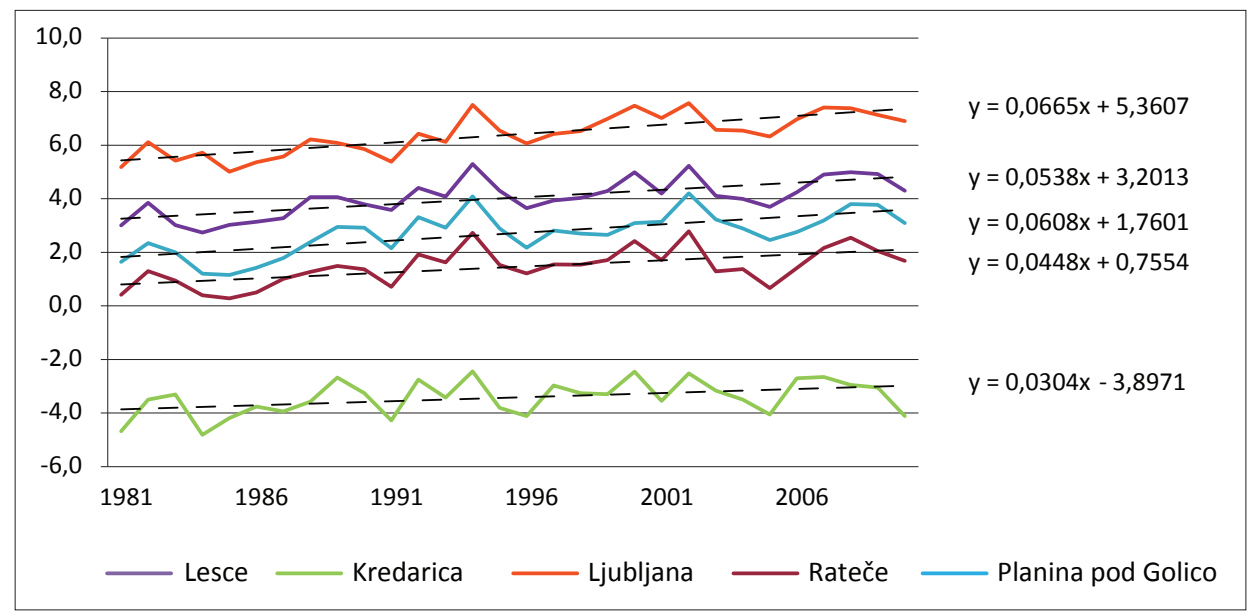

Vir/Source: Arhiv ARSO, 2012

Preglednica 1: Tridesetletni trendi povprečnih, povprečnih najvišjih in povprečnih najnižjih dnevnih temperatur $\left({ }^{\circ} \mathrm{C}\right)$ na izbranih meteoroloških postajah v obdobju 1981-2010

Table 1: Linear trends of thirty years period for mean, mean maximum and mean minimum daily temperatures on chosen meteorological stations in the period 1981-2010

\begin{tabular}{|l|c|c|c|c|c|}
\hline 30-letni trend $\left({ }^{\circ} \mathbf{C}\right)$ & $\begin{array}{c}\text { Ljubljana- } \\
\text { Bežigrad }\end{array}$ & Lesce & Rateče & $\begin{array}{c}\text { Planina pod } \\
\text { Golico }\end{array}$ & Kredarica \\
\hline $\mathrm{T}_{\text {povp }}$ & 2,0 & 1,5 & 1,5 & 1,2 & 0,7 \\
\hline $\mathrm{T}_{\text {maks }}$ & 1,9 & 1,7 & 1,8 & 1,8 & 0,8 \\
\hline $\mathrm{T}_{\min }$ & 2,0 & 1,6 & 1,3 & 1,8 & 0,9 \\
\hline
\end{tabular}

Vir/Source: Arhiv ARSO, 2012

Povprečna najvišja dnevna temperatura kaže trend zviševanja na vseh postajah (slika 3). V Ljubljani znaša tridesetletni trend $1,9{ }^{\circ} \mathrm{C}, \mathrm{v}$ Lescah $1,7{ }^{\circ} \mathrm{C}$, v Ratečah in na Planini pod Golico $1,8{ }^{\circ} \mathrm{C}$ ter na Kredarici $0,8{ }^{\circ} \mathrm{C}$ (preglednica 1).

Tudi trendi povprečnih najnižjih dnevnih temperatur so večinoma podobni trendom povprečnih najvišjih temperatur (slika 4), le v Ratečah je porast opazno manjši, kar lahko pojasnimo z vplivom izrazitega toplotnega obrata, ki zavira ogrevanje. Trendi za $30-$ letno obdobje sicer znašajo v Ljubljani $2{ }^{\circ} \mathrm{C}$, v Lescah $1,6{ }^{\circ} \mathrm{C}$, na Planini pod Golico $1,8{ }^{\circ} \mathrm{C}$, v Ratečah $1,3{ }^{\circ} \mathrm{C}$ in na Kredarici le $0,9{ }^{\circ} \mathrm{C}$ (preglednica 1$)$. 
Če pogledamo aritmetične sredine vseh treh trendov za izbrane postaje Gorenjske, vidimo, da z nadmorsko višino padajo, le med Ratečami in Planino pod Golico se ta trend popači. V Ljubljani znaša $2{ }^{\circ} \mathrm{C}$, v Lescah $1,6{ }^{\circ} \mathrm{C}$, v Ratečah $1,5{ }^{\circ} \mathrm{C}$, na Planini pod Golico $1,6^{\circ} \mathrm{C}$ ter na visokogorski Kredarici le še okoli $0,8{ }^{\circ} \mathrm{C}$. Pri Ljubljani trend zagotovo ni posledica samo globalnih vzrokov, ki jih največkrat povezujemo z globalnim ogrevanjem, nujno je potrebno upoštevati tudi širjenje mesta in pojav oziroma krepitev mestnega toplotnega otoka (Jernej, 2000) zaradi širjenja mesta. Pri ostalih postajah ta pojav ni prisoten. Lesce so tipična kotlinska, Rateče pa tipična dolinska postaja, kjer je malo advektivnega vremena in toliko več radiacijskega. Na obeh postajah se redno pojavlja toplotni obrat, ki je v Ratečah še posebej izrazit v hladni polovici leta in zlasti ob snežni odeji. Verjetno gre $\mathrm{v}$ tem iskati vzrok počasnejšega nočnega ogrevanja v zadnjih 30 letih, saj ga pogost pojav jezera hladnega zraka upočasnjuje. Planina pod Golico je po nadmorski višini sicer blizu Ratečam, a se nahaja v povsem drugačnem okolju, na manjši uravnavi na prisojni strani Karavank nad Dolino, običajno nad zgornjo mejo toplotnega obrata. Morda bi lahko celo rekli, da se postaja nahaja v termalnem alpskem pasu, kar pomeni, da ne gre za termalni pas v izvirnem pomenu besede, saj se ta nanaša na nadmorske višine pod okoli $500 \mathrm{~m}$ v svetu hribovij in gričevij. Planina pod Golico se torej nahaja v pasu, ki je toplejši od nižje ležečih leg, ki jih zaznamuje manjša osončenost in dlje trajajoči toplotni obrat, toplejši pa je tudi od višjih leg, kjer temperatura pada z višino. Meteorološka postaja Kredarica je zaradi lege v visokogorju izrazito izpostavljena vetrovom, zato so prirasti tako dnevnih kot nočnih temperatur manjši.

Tudi preglednica 2 nam pokaže podobno sliko kot ostali trendi v zadnjih tridesetih letih, le da so razlike precej manjše. V primerjavi z obdobjem 1961-1990 je bilo obdobje 1981-2010 v Ljubljani toplejše za 0,9 ${ }^{\circ} \mathrm{C}$, v Ratečah le za desetinko manj, še desetinko manj pa je bilo zadnjih 30 let v primerjavi z obdobjem 1961-1990 topleje v visokogorju.

Preglednica 2: Primerjava povprečnih letnih temperatur $\left({ }^{\circ} \mathrm{C}\right)$ na izbranih meteoroloških postajah $v$ obdobjih 1961-1990 in 1981-2010

Table 2: Comparison of mean annual temperatures $\left({ }^{\circ} \mathrm{C}\right)$ on chosen meteorological stations in the periods 1961-1990 and 1981-2010

\begin{tabular}{|l|c|c|c|}
\hline & $\begin{array}{c}\text { Ljubljana- } \\
\text { Bežigrad }\end{array}$ & Rateče & Kredarica \\
\hline $\mathrm{T}_{\text {povp }}\left({ }^{\circ} \mathrm{C}\right) 1961-1990$ & 9,8 & 5,7 & $-1,7$ \\
\hline $\mathrm{T}_{\text {povp }}\left({ }^{\circ} \mathrm{C}\right) 1981-2010$ & 10,7 & 6,5 & $-1,0$ \\
\hline Sprememba T & 0,9 & 0,8 & 0,7 \\
\hline
\end{tabular}

Vir/Source: Arhiv ARSO, 2012 
Slika 5: Smučišče Španov vrh na nadmorski višini med 1000 in 1400 m se nahaja nad Planino pod Golico in zaradi ogrevanja ozračja ter nestalnosti snežne odeje obratuje le še občasno (foto: M. Ogrin)

Figure 5: Ski area Španov vrh lies above Planina pod Golico on elevation between 1000 and $1400 \mathrm{~m}$; due to global warming, nowadays it operates only occasionally (photo: M. Ogrin)

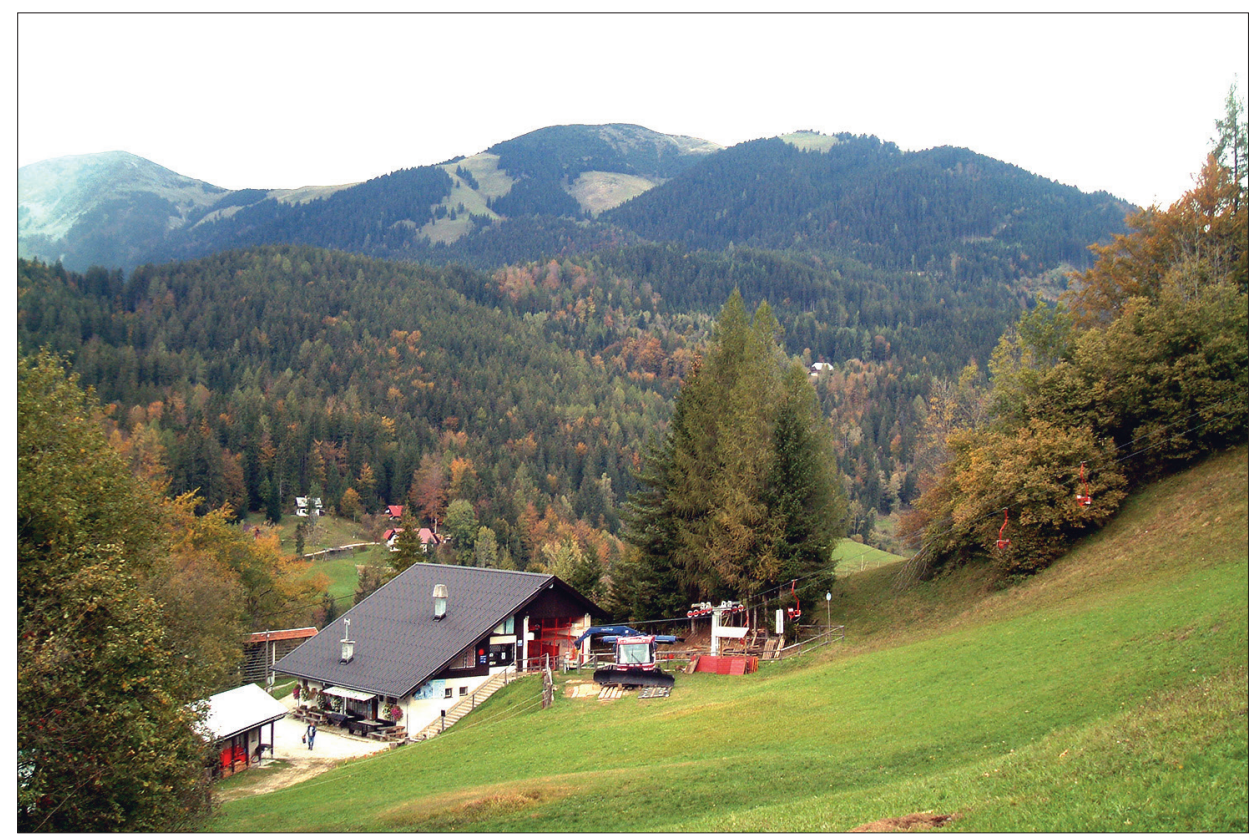

\section{I. Karakteristični dnevi}

$\mathrm{Na}$ vseh petih preučevanih meteoroloških postajah je opazen trend zmanjševanja števila mrzlih in hladnih dni (preglednica 3). V Ljubljani in v Lescah se je število mrzlih dni v 30 letih zmanjšalo za en teden, v Ratečah in na Planini pod Golico za skoraj dva tedna, na Kredarici za 11 dni. Precej hitreje upadajo hladni dnevi: Ljubljana, Rateče in Lesce beležijo trend treh do štirih tednov manj hladnih dni na leto, na Planini pod Golico je teh tednov skoraj pet, na Kredarici pa le dva in pol. Porast števila toplih dni je nekoliko manjši od upada hladnih dni: v Ljubljani in na Planini pod Golico beležimo trend rasti v dolžini približno dveh tednov in pol, v Lescah in Ratečah beležijo rast približno treh tednov, na Kredarici pa toplega dneva še niso zabeležili. Trend porasta vročih dni je najbolj opazen v Ljubljani, saj med izbranimi postajami edini dosega več kot deset dni (16), v Lescah devet dni, v Ratečah šest dni, na Planini pod Golico, ki je že na mejnem območju za pojav vročih dni, pa beležijo tridesetletni trend rasti le dva dneva. 
Preglednica 3: Tridesetletni trendi števila karakterističnih dni na leto na izbranih meteoroloških postajah v obdobju 1981-2010

Table 3: Thirty years trends of characteristic days per year on chosen meteorological stations in the period 1981-2010

\begin{tabular}{|l|c|c|c|c|c|}
\hline & $\begin{array}{c}\text { Ljubljana- } \\
\text { Bežigrad }\end{array}$ & Lesce & Rateče & $\begin{array}{c}\text { Planina pod } \\
\text { Golico }\end{array}$ & Kredarica \\
\hline Mrzli dnevi & -7 & -7 & -13 & -13 & -11 \\
\hline Hladni dnevi & -26 & -23 & -26 & -34 & -18 \\
\hline Topli dnevi & 18 & 22 & 23 & 19 & 0 \\
\hline Vroči dnevi & 16 & 9 & 6 & 2 & 0 \\
\hline
\end{tabular}

Vir/Source: Arhiv ARSO, 2012

Preglednica 4: Primerjava povprečnega števila mrzlih dni na leto v obdobjih 1961-1990 in 1981-2010 na izbranih meteoroloških postajah

Table 4: Comparison of average number of cold days par year on chosen meteorological stations in the periods 1961-1990 and 1981-2010

\begin{tabular}{|l|c|c|c|c|}
\hline & $\begin{array}{c}\text { Ljubljana- } \\
\text { Bežigrad }\end{array}$ & Rateče & $\begin{array}{c}\text { Planina pod } \\
\text { Golico }\end{array}$ & Kredarica \\
\hline Število mrzlih dni $1961-1990$ & 7 & 37 & 17 & 76 \\
\hline Število mrzlih dni $1981-2010$ & 5 & 32 & 14 & 70 \\
\hline Razlika & $-2(-28 \%)$ & $-5(-14 \%)$ & $-3(-18 \%)$ & $-6(-8 \%)$ \\
\hline
\end{tabular}

Vir/Source: Arhiv ARSO, 2012

Preglednica 4 kaže primerjavo povprečnega števila mrzlih dni v obdobjih 1961-1990 in 1981-2010, iz nje pa je prav tako razviden upad števila mrzlih dni na vseh izbranih meteoroloških postajah. Absolutni upad je na vseh postajah podoben in znaša od dva do šest dni, večja pa je razlika v relativnem upadu. Razumljivo je v visokogorju zaznati najmanjši relativni upad (8 \%), še vedno pa je takih dni kar za deset tednov. V Ratečah, kjer je zlasti pozimi pogost toplotni obrat, je bilo v zadnjem 30-letnem obdobju mrzlih dni za približno štiri tedne in pol na leto, zabeležili pa so 14-odstotni upad. Na Planini pod Golico sta 'mrzla' le dva tedna, pri čemer beležijo 18-odstotni upad glede na prejšnje obdobje. Največji, kar 28-odstotni upad mrzlih dni se je zgodil v Ljubljani, kjer je bilo v zadnjem 30-letnem obdobju le še pet mrzlih dni na leto. 
Slika 6: Spreminjanje števila mrzlih dni z linearnimi trendi na izbranih meteoroloških postajah v obdobju 1980-2010

Figure 6: Changing of number of cold days with linear trends on chosen meteorological stations in the period 1980-2010

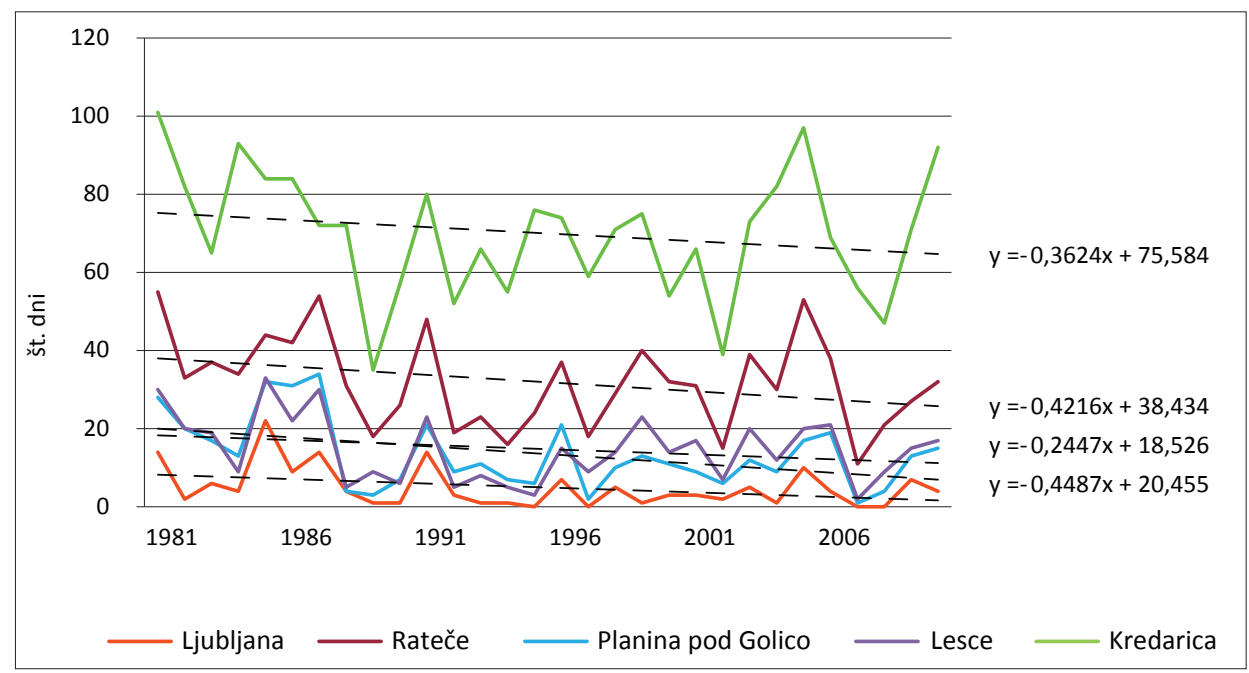

Vir/Source: Arhiv ARSO, 2012

Preglednica 5: Primerjava povprečnega števila hladnih dni na leto v obdobjih 1961-1990 in 1981-2010 na izbranih meteoroloških postajah

Table 5: Comparison of average number of cold days per year on chosen meteorological stations in the periods 1961-1990 and 1981-2010

\begin{tabular}{|l|c|c|c|c|}
\hline & $\begin{array}{c}\text { Ljubljana- } \\
\text { Bežigrad }\end{array}$ & Rateče & $\begin{array}{c}\text { Planina pod } \\
\text { Golico }\end{array}$ & Kredarica \\
\hline Povprečno število hladnih dni 1961-1990 & 92 & 169 & 145 & 253 \\
\hline Povprečno število hladnih dni 1981-2010 & 81 & 152 & 131 & 237 \\
\hline Razlika & $-11(-12 \%)$ & $-17(-10 \%)$ & $-14(-10 \%)$ & $-16(-6 \%)$ \\
\hline
\end{tabular}

Vir/Source: Arhiv ARSO, 2012

Relativni upad števila hladnih dni v preučevanih obdobjih je na vseh izbranih postajah podoben; če izvzamemo Kredarico, znaša okoli deset odstotkov (preglednica 5). Razumljivo je hladnih dni precej več kot mrzlih, po nižinah se večinoma pojavijo v vseh letnih časih z izjemo poletja, v visokogorju tudi poleti. Na Kredarici so hladni dnevi skoraj dve tretjini leta, v Ratečah približno štiri desetine, na Planini pod Golico malo več kot tretjino in v Ljubljani dobro petino leta. 
Slika 7: Spreminjanje števila hladnih dni z linearnimi trendi na izbranih meteoroloških postajah v obdobju 1981-2010

Figure 7: Changing of number of cold days with linear trends on chosen meteorological stations in the period 1981-2010

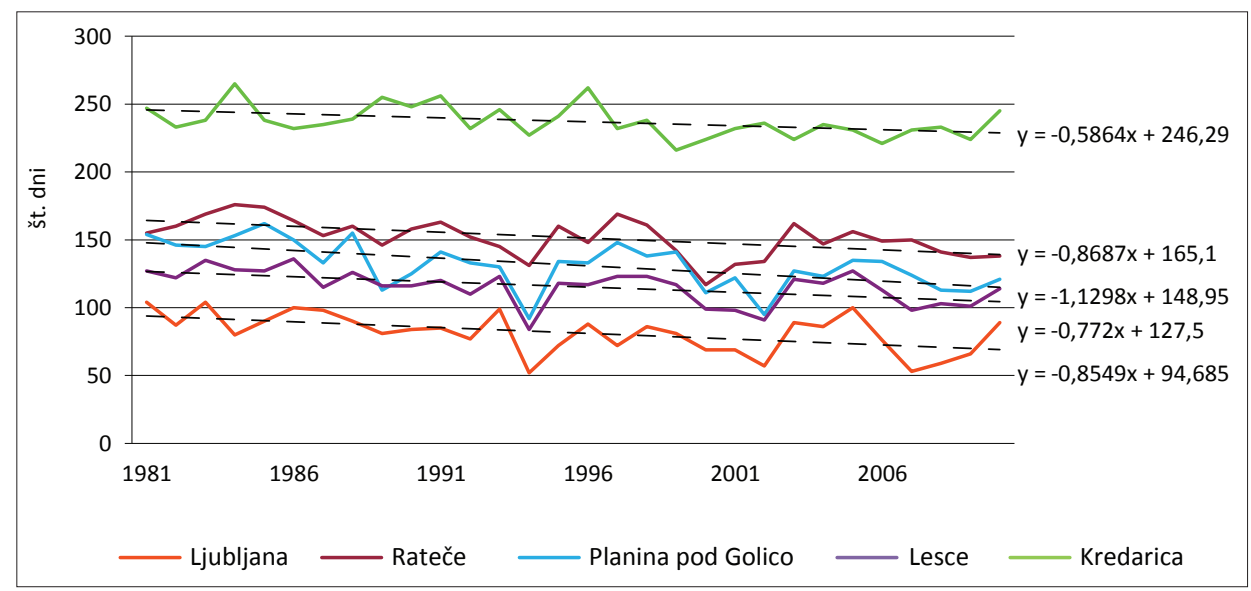

Vir/Source: Arhiv ARSO, 2012

Preglednica 6: Primerjava povprečnega števila toplih dni na leto v obdobjih 1961-1990 in 1981-2010 na izbranih meteoroloških postajah

Table 6: Comparison of average number of warm days per year in the periods 1961-1990 and $1981-2010$

\begin{tabular}{|l|c|c|c|c|}
\hline & $\begin{array}{c}\text { Ljubljana- } \\
\text { Bežigrad }\end{array}$ & Rateče & $\begin{array}{c}\text { Planina pod } \\
\text { Golico }\end{array}$ & Kredarica \\
\hline Povprečno število toplih dni 1961-1990 & 61 & 22 & 12 & 0 \\
\hline Povprečno število toplih dni 1981-2010 & 73 & 33 & 23 & 0 \\
\hline Razlika & $12(19 \%)$ & $11(50 \%)$ & $11(92 \%)$ & 0 \\
\hline
\end{tabular}

Vir/Source: Arhiv ARSO, 2012

Tudi toplih dni je na Gorenjskem v povprečju razmeroma veliko, a vseeno opazno manj kot hladnih (preglednica 6). Z izjemo zime se zlasti po nižinah (Ljubljana) lahko pojavijo v vseh letnih časih, v višjih legah (Rateče in Planina pod Golico) pa spomladi in poleti, manj verjetno pa jeseni. Pričakovano je imelo zadnje 30-letno obdobje več toplih dni od prejšnjega na vseh meteoroloških postajah, kjer se pojavljajo. Na Kredarici takih dni ni, saj je bila tam doslej najvišja izmerjena temperatura $21,6{ }^{\circ} \mathrm{C}$ (27. 7. 1983; Arhiv ARSO, 2012), na ostalih postajah je absolutni porast skoraj enak in znaša 11 oziroma 12 dni. Bistvena razlika je v relativnem porastu, saj 12 več toplih dni v Ljubljani pomeni le 19-odstotni porast, v Ratečah pa 11 dni kar 50-odstotni, na Planini pod Golico pa 11 dni kar 92-odstotni porast. 
Slika 8: Spreminjanje števila toplih dni na leto z linearnimi trendi na izbranih meteoroloških postajah v obdobju 1980-2010

Figure 8: Changing of number of warm days per year with linear trends on chosen meteorological stations in the period 1980-2010

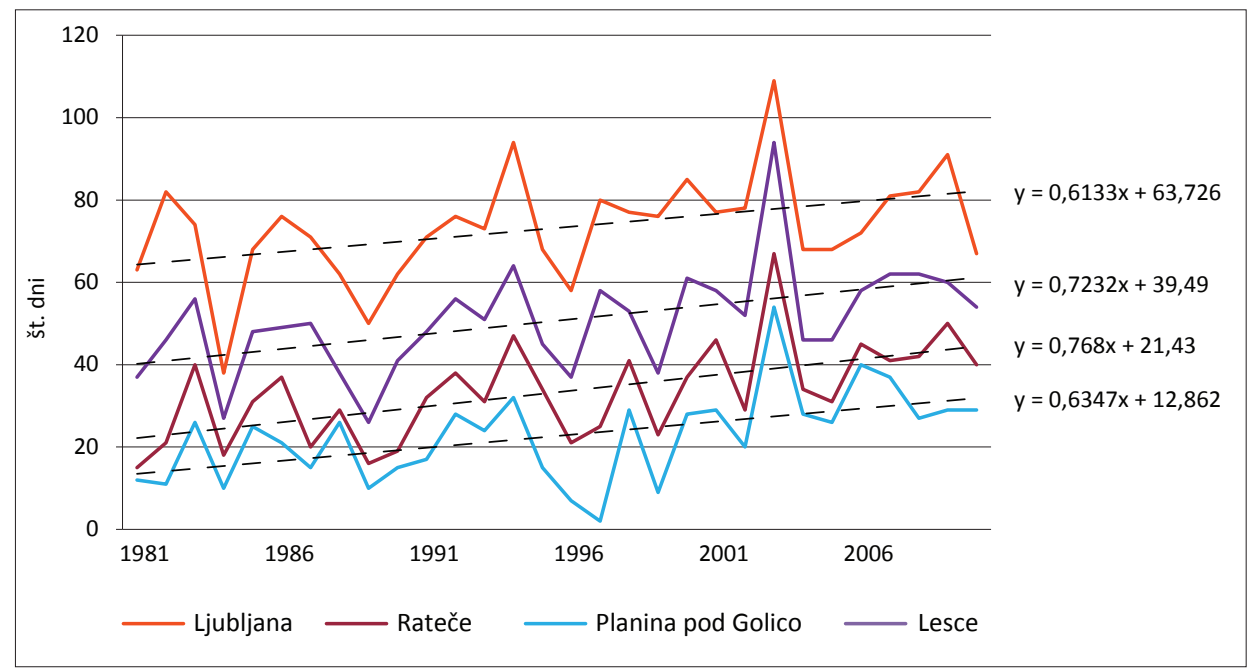

Vir/Source: Arhiv ARSO, 2012

Preglednica 7: Primerjava povprečnega števila vročih dni na leto v obdobjih 1961-1990 in 1981-2010 na izbranih meteoroloških postajah

Table 7: Comparison of average number of hot days per year in the periods 1961-1990 and 1981-2010

\begin{tabular}{|l|c|c|c|}
\hline & $\begin{array}{c}\text { Ljubljana- } \\
\text { Bežigrad }\end{array}$ & Rateče & $\begin{array}{c}\text { Planina pod } \\
\text { Golico }\end{array}$ \\
\hline Povprečno število vročih dni 1961-1990 & 11 & 0,6 & 0,1 \\
\hline Povprečno število vročih dni 1981-2010 & 19 & 3,5 & 0,8 \\
\hline Razlika & 8 & 2,9 & 0,7 \\
\hline
\end{tabular}

Vir/Source: Arhiv ARSO, 2012

Vroči dnevi so kazalec pravega poletnega vremena, saj temperatura v takih dneh preseže $30^{\circ} \mathrm{C}$. Po nižinah Gorenjske se pojavljajo spomladi in poleti, jeseni pa praviloma ne več. V višjih legah so taki dnevi redki, opazi pa se, da so v Ratečah v zadnjem obdobju trije ali štirje taki dnevi, v prejšnjem obdobju pa se vroč dan niti ni pojavil vsako leto. Tudi na Planini pod Golico je bil v prejšnjem obdobju vroč dan zelo redek pojav, saj se je pojavil le enkrat na deset let, v zadnjem obdobju pa se pojavlja v povprečju kar osemkrat v desetih letih. V Ljubljani je bilo v zadnjem obdobju vročih dni v povprečju že za skoraj tri tedne, $v$ prejšnjem pa približno teden in pol (preglednica 7). Porast je bil kar 
Slika 9: Spreminjanje števila vročih dni na leto z linearnimi trendi na izbranih meteoroloških postajah v obdobju 1981-2010

Figure 9: Changing of number of hot days per yer with linear trends on chosen meteorological stations in the period 1981-2010

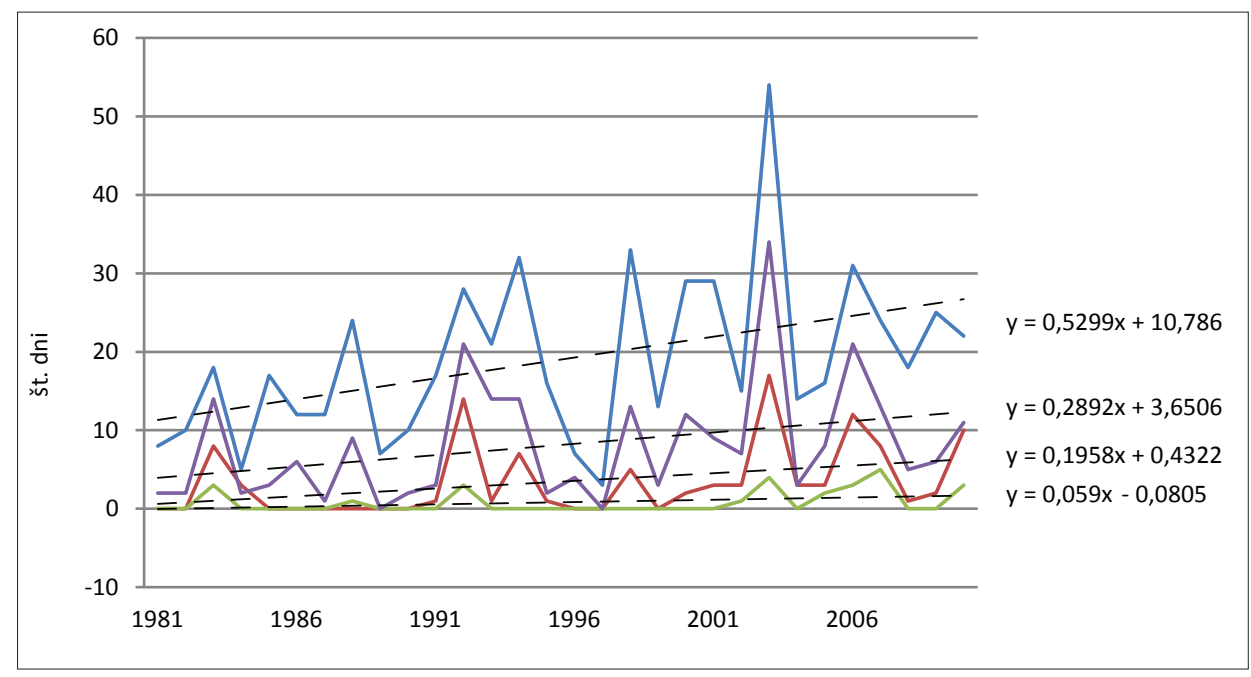

Vir/Source: Arhiv ARSO, 2012

Preglednica 8: Število toplih noči na leto v Ljubljani in Lescah

Table 8: The number of warm nights in Ljubljana and Lesce

\begin{tabular}{|l|c|c|}
\hline & $\begin{array}{c}\text { Ljubljana- } \\
\text { Bežigrad }\end{array}$ & Lesce \\
\hline Povprečno število toplih noči 1961-1990 & 0 & 0 \\
\hline Povprečno število toplih noči 1981-2010 & 1,4 & 0,1 \\
\hline
\end{tabular}

Vir/Source: Arhiv ARSO, 2012

73-odstoten in nakazuje, da postajajo vročinski valovi v Ljubljani stalnica, enako tudi v nižjih predelih Gorenjske.

Če kot zanimivost pogledamo še pojav toplih noči, ki so v Sloveniji še vedno precej redek pojav, vidimo, da so se v zadnjem obdobju pojavljale le v Ljubljani in komaj kaj tudi v Lescah (za Lesce ni podatka iz obdobja 1961-1990). Vsekakor pa je v Ljubljani že običajno, da se vsako leto pojavi vsaj ena topla noč, česar v preteklem obdobju ni bilo. 


\section{SKLEP}

Primerjave temperatur v obdobjih 1961-1990 in 1981-2010 ter analiza obdobja 1981-2010 so pokazale, da tudi na Gorenjskem beležimo znaten porast temperatur, najsi gre za povprečne dnevne, povprečne najnižje ali povprečne najvišje dnevne temperature. V nižjih legah znašajo 30-letni linearni trendi od $1,5-2{ }^{\circ} \mathrm{C}$ tako pri povprečnih dnevnih, kot pri povprečnih najvišjih in povprečnih najnižjih dnevnih temperaturah. Za podatke $\mathrm{z}$ meteorološke postaje Ljubljana-Bežigrad moramo dodati, da so časovne vrste obremenjene s členom krepitve mestnega toplotnega otoka (Jernej, 2000), a na žalost v Sloveniji ne razpolagamo z drugim, dovolj dolgim in dovolj kakovostnim nizom meritev na lokaciji, ki bi bila bolj reprezentativna za spodnje dele Gorenjske. Kot lokacija bi bila veliko primernejša meteorološka postaja na letališču Jožeta Pučnika na Brniku, a so nizi nehomogeni in nepopolni. Z nadmorsko višino se trend ogrevanja nekoliko upočasni, saj znaša V sredogorju oziroma na nadmorski višini okoli $1000 \mathrm{~m}$ pri povprečnih dnevnih temperaturah $1,5-1,2{ }^{\circ} \mathrm{C}$, pri povprečnih najvišjih dnevnih $1,8^{\circ} \mathrm{C}$, pri povprečnih najnižjih dnevnih v alpskih dolinah le $1,3{ }^{\circ} \mathrm{C}$ in $1,8^{\circ} \mathrm{C}$ v vzpetem sredogorskem svetu.

Ugotavljamo, da dolinska lega s pogostim toplotnim obratom zavira učinek globalnega ogrevanja. Če gremo še višje, v visokogorje, nam podatki z naše edine visokogorske meteorološke postaje na Kredarici $(2514 \mathrm{~m})$ razkrijejo, da se tam ozračje ogreva še počasneje: 30-letni trend znaša le $0,7^{\circ} \mathrm{C}$ za povprečne dnevne temperature, pri povprečnih najvišjih dnevnih $0,8{ }^{\circ} \mathrm{C}$ in pri povprečnih najnižjih dnevnih $0,9^{\circ} \mathrm{C}$. Pri primerjavi povprečnih temperatur zraka med postajami Ljubljana-Bežigrad, Rateče in Kredarica se je pokazalo, da so temperature zadnjega obdobja višje za $0,7-0,9^{\circ} \mathrm{C}$, pri čemer je treba vedeti, da je za visokogorje ta vrednost enaka 30-letnemu trendu, medtem ko je za nižine (postaji Rateče in Ljubljana-Bežigrad) ta razlika nekoliko (Rateče: $0,7^{\circ} \mathrm{C}$ ) oziroma bistveno (Ljubljana-Bežigrad: $1,1^{\circ} \mathrm{C}$ ) manjša od trenda.

Analiza 30-letnega trenda karakterističnih dni je pokazala, da se je število mrzlih dni na leto po nižinah zmanjšalo za en teden, v sredogorju za slaba dva tedna in v visokogorju za poltretji teden. Število hladnih dni je po nižinah upadlo za približno tri tedne in pol, najbolj opazen upad, skoraj pet tednov, pa kaže trend v sredogorju, medtem ko v visokogorju spet pade in znaša približno dva tedna in pol.

Število vročih dni je najhitreje (9-16 dni/30 let) naraščalo v nižinah, dolinah in sredogorju (2-6 dni), pri čemer višji del intervala pripada dolinam, ki so sredi dneva manj prevetrene in se poleti bolj pregrejejo. Tudi primerjava povprečnega števila karakterističnih dni za obdobji 1961-1990 in 1981-2010 je zgovorna in pove, da so vroči dnevi danes vsakoleten, tri do štirikraten pojav v alpskih dolinah, v prejšnjem obdobju pa so se pojavili le povprečno šestkrat v desetih letih. V sredogorju, na nadmorski višini okoli 1000 m, je bilo v zadnjem obdobju povprečno osem vročih dni v desetih letih, v prejšnjem obdobju pa so na takih območjih beležili le en dan vroč dan v desetih letih. V nižjih delih Gorenjske znaša povprečje vročih dni zadnjih 30 let dva tedna do dva tedna in pol. V Ljubljani se je povprečje glede na prejšnje obdobje povečalo z 11 na 19 dni in če predpostavljamo, da se skoraj vedno vsi vroči dnevi pojavljajo med 15. majem in 15. septembrom, pomeni, da je v tem obdobju vroč že skoraj vsak šesti dan. 
Tudi število toplih dni se je precej povečalo: $\mathrm{v}$ sredogorju se je na okoli $1000 \mathrm{~m}$ nadmorske višine njihovo število skoraj podvojilo in znaša že tri tedne in dva dni, $v$ alpskih dolinah se je število teh dni povečalo za polovico in znaša sedaj 33 dni, po nižinah pa se je povečalo le za slabo petino in znaša skoraj dva meseca in pol.

Za Gorenjsko je bilo vedno značilno razmeroma hladno in vlažno podnebje z dolgo zimo in razmeroma svežimi poletji. Mnogi so jo označevali celo za najhladnejšo slovensko pokrajino, čeprav danes vemo, da planote Notranjske glede mraza v ničemer ne zaostajajo za njo. Temperaturni trendi, ki jih kažejo analize podatkov, nakazujejo postopno omilitev podnebnih razmer na Gorenjskem, vsaj kar zadeva mrzla in hladna obdobja, opazen porast števila toplih in redno pojavljanje vročih dni pa nakazujeta tudi ogrevanje poletij oziroma tople polovice leta. V Ljubljani tudi tople noči niso več izjema.

Ti trendi sporočajo gorenjskim turističnim krajem, da je lahko trend ogrevanja ozračja zanje tudi priložnost krepitve poletnega turizma, ko bodo ljudje iskali kraje za osvežitev. Hkrati trendi, ki se kažejo v toplejših zimah, zahtevajo premišljena vlaganja v vrste in obseg zimskega turizma, saj so temperaturni pogoji za zagotovitev naravne ali umetne snežne odeje vse manj ugodni.

Padavinskih razmer $\mathrm{v}$ tej raziskavi nismo obravnavali, a iz študije, ki sta jo opravila Dolinar in Vertačnik (2010, str. 40) sledi, da se količina padavin v Sloveniji spreminja predvsem med letnimi časi, na letni ravni pa zelo malo. Če to ugotovitev povežemo z rastjo temperatur, to pomeni večje izhlapevanje in 'boljše' pogoje za pojav sušnosti, tako da morda Gorenjska v prihodnjih desetletjih ne bo več znana kot razmeroma mokra in vselej dobro namočena pokrajina $\mathrm{z}$ obiljem vode. Zanimivi izzivi za fizično geografijo se odpirajo tudi glede drugih, še dolgoročnejših učinkov teh podnebnih sprememb, npr. na pojavljanje vremenskih ujm, rastlinstvo, erozijske in druge naravne procese (Natek, Mrak, Braucher, 2013).

\section{Viri in literatura}

Arhiv ARSO. 2013. URL: http://meteo.arso.gov.si/met/sl/app/webmet/\#webmet==8S dwx2bhR2cv0WZ0V2bvEGcw9ydlJWblR3LwVnaz9SYtVmYh9iclFGbt9Sau1 GdugXbsx3cs9md15 WahxXYyNGapZXZ8tHZv1 WYp5mOnMHbvZXZulWYnwCchJXYtVGdlJnOn0UQQdSf (Citirano 10. 12. 2013).

Böhm, R., Auer, I., Brunetti, M., Maugeri, M., Nanni, T., Schöner, W., 2001. Regional temperature variability in the European Alps: 1760-1998 from homogenized instrumental time series. International journal of climatology, 21, 14, str. 1779-1801.

Dolinar, M., Vertačnik, G., 2010. Spremenljivost temperaturnih in padavinskih razmer v Sloveniji. V: Cegnar, T. (ur.). Okolje se spreminja. Podnebna spremenljivost Slovenije in njen vpliv na vodno okolje. Ljubljana, ARSO, str. 37-40. URL: http:// www.arso.gov.si/novice/datoteke/025928-Okolje\%20se\%20spreminja.pdf (Citirano 10. 12. 2013).

Jernej, S. 2000. Mestna klima. V: Gabrovec, M., Orožen Adamič, M. (ur.). Ljubljana: geografija mesta. Ljubljana, LGD, Založba ZRC, str. 117-130. 
Natek, K., Mrak, I., Braucher, R., 2013. Časovna dimenzija naravnih procesov v luči novih možnosti absolutne datacije: primeri z Gorenjskega. V: Rogelj, B., Slavič Potočnik, I., Mrak, I. (ur). Gorenjska v obdobju glokalizacije. Ljubljana, Znanstvena založba Filozofske fakultete, str. 75-84.

Neu, U., 2009. Climate change in mountains. V: Kohler, T., Maselli, D. ( ur.). Mountains and climate change. From understanding to action. Bern. Geographica Bernensia with the support of the Swiss Agency for Development and Cooperation (SDC), and an international team of contributors. URL: http://www.fao.org/docrep/017/i2869e/ i2869e00.pdf (Citirano 10. 12. 2013).

Ogrin D., 2003. Spreminjanje temperature zraka in padavin po letnih časih v Ljubljani in Trstu v obdobju 1851-2002. Dela, 20, str. 115-131.

Ogrin, D., Vysoudil, M., Ogrin, M., 2013. Splošne podnebne razmere Gorenjske in lokalno podnebje Kamniške Bistrice. V: Rogelj, B., Slavič Potočnik, I., Mrak, I. (ur). Gorenjska v obdobju glokalizacije. Ljubljana, Znanstvena založba Filozofske fakultete, str. 9-30.

Ogrin, M., Ogrin, D., Močnik, M., Smolej, A., Vengar, R., 2009. Študija klimatskih razmer za oceno smotrnosti širjenja smučišča Španov vrh nad Jesenicami in bioklimatska študija za območje Planine pod Golico. Končno poročilo raziskovalne naloge. Ljubljana, Filozofska fakulteta, Oddelek za geografijo, 84 str.

Ogrin, M., Ogrin, D., Močnik, M., Smolej, A., Vengar, R., 2011. Prihodnost zimskega turizma na Planini pod Golico v luči globalnega segrevanja. Dela, 36, str. 5-23.

Vrtačnik Garbas, K., 2008. Posledice klimatske spremenljivosti v središčih zimsko-športne rekreacije v Sloveniji. Doktorska disertacija. Ljubljana, Filozofska fakulteta, Oddelek za geografijo. 480 str.

\section{TEMPERATURE CHANGES OF GORENJSKA REGION IN THE PERIOD I96I-20I0}

\section{Summary}

The article shows temperature conditions and temperature changes of Gorenjska region. Authors compared data for two 30-years long periods (1961-1990 and 1981-2010) from five meteorological stations of Slovenian Environmental Agency. Kredarica is located in Julian Alps at $2514 \mathrm{~m}$, the station Planina pod Golico $(970 \mathrm{~m})$ is located on southern slopes of Karavanke on small plateau above Dolina valley, the station Rateče (864 m) lies on highest point of Dolina valley, the station Lesce $(515 \mathrm{~m})$ is in the northwestern part of Ljubljana Basin, and station Ljubljana-Bežigrad is located on the edge of Gorenjska region also in the bottom of the Ljubljana Basin.

The comparison of both periods confirmed similar trends of temperature increase as in other regions. In lowland, 30-year linear trends show an increase of 1,5 to $2^{\circ} \mathrm{C}$ for mean daily temperature, mean daily maximum and mean daily minimum temperatures. On higher elevations, these trends show smaller increase: $1,2{ }^{\circ} \mathrm{C}$ for mean daily temperatures 
and $1,8{ }^{\circ} \mathrm{C}$ for mean daily maximum temperatures. For mean daily minimum temperatures in Alpine valleys at elevation around $900 \mathrm{~m}$, the trend is $1,3{ }^{\circ} \mathrm{C}$ and on southern slopes, at the same elevation, it is $1,8^{\circ} \mathrm{C}$. For the highest parts of Slovenian mountains, linear trends show even smaller increase - for mean daily temperatures it is $0,7^{\circ} \mathrm{C}$, for mean maximum temperatures $0,8^{\circ} \mathrm{C}$ and for mean minimum temperatures $0,9^{\circ} \mathrm{C}$.

If we compare average temperatures for Ljubljana-Bežigrad, Rateče and Kredarica from both periods, we see that the temperature increased for $0,7-0,9^{\circ} \mathrm{C}$. Analysis also showed that number of cold days $\left(\mathrm{T}_{\min }<-10{ }^{\circ} \mathrm{C}\right)$ during the 30-years period 1981-2010 decreased in lowlands for seven, on elevations around $1000 \mathrm{~m}$ for 13, and in high mountains (around $2500 \mathrm{~m}$ ) it decreased for 11 days. In general, the results also show decrease of cool days $\left(\mathrm{T}_{\min }<0{ }^{\circ} \mathrm{C}\right)$ and frost days $\left(\mathrm{T}_{\max }<0{ }^{\circ} \mathrm{C}\right)$ and increase of warm days $\left(\mathrm{T}_{\max }>25^{\circ} \mathrm{C}\right)$ and hot days $\left(\mathrm{T}_{\max }>30^{\circ} \mathrm{C}\right)$ during the same period.

In Rateče, situated in an Alpine valley, during the last period 1981-2010, there were three to four hot days/year whereas in the period 1961-1990 there was only 0,6 day/year or six days per ten years. On Planina pod Golico station, there was almost one $(0,8)$ hot day/year in last period and only one day per ten years $(0,1$ day/year) in previous period. Analysis show gradual warming of Gorenjska region which brings new problems to winter tourism and also new challenges to summer tourism, where we can expect more pressure on higher Alpine resorts of Gorenjska region. Warming trends also indicate possible water problems in summer periods although Gorenjska is traditionally known as humid land with abundant water resources. 